\title{
Malaysian Trade Policy and the 2001 WTO Trade Policy Review
}

\author{
Prema-chandra Athukorala
}

\begin{abstract}
The purpose of this paper is two-fold; to examine developments in trade and investment policy regimes in Malaysia following the on-set of the financial crisis, using the Trade Policy Review Malaysia 2001 of the WTO as a reference point; and to evaluate the Review in terms of the objectives of the WTO Trade Policy Review Mechanism as set out in the Marrakesh Agreement. It is found that, by and large Malaysia has managed to come out of the crisis without compromising on its long-standing commitment to maintaining a relatively open trade and investment policy regime by the regional standards. However, there are some disturbing post-crisis developments, which deserve scrutiny in a future Review. These include increase in the degree of dispersion of tariff rates because of high tariff peaks relating to a few product lines, increased reliance on non-automatic import licensing to regulate imports of a significant number of products which directly compete with domestic production by public sector enterprises, and unexplained delays in meeting commitments under the General Agreement on Trade in Services (GATS)
\end{abstract}

JEL Classification: F13, F14, O53

Forthcoming in The World Economy (Annual Issue: Global Trade Policy 2002) 


\section{Malaysian Trade Policy and the 2001 WTO Trade Policy Review}

\section{INTRODUCTION}

The trade Policy Mechanism (TPRM) is a collective review process of the World Trade Organisation that aims to contribute to improved adherence by Member countries to rules and commitments set out in the WTO Agreement. ${ }^{1}$ Under the TPRM, trade and related policies of member countries are examined and evaluated at regular intervals by the Trade Policy Review Body (TPRB), a full-membership body of equal ranking to the General Council and the Dispute Settlement Body. Each country review is based on two reports independently prepared by the WTO Secretariat (the main report) and the government of the country under review covering all aspects of the trade policies, including the domestic laws and regulations, the institutional framework; bilateral, regional and other preferential agreements and the external environment. The two reports and the proceedings of the TPRB meetings are published under the general title of Trade Policy Review [Country, Year]. These review reports, which are available both in printed form and electronically (on the WTO website) from the Secretariat, have now become an important part of the literature on global trade policy. The frequency of review of a given country depends on its relative position in global trade. The four largest entities (the European Union (EU), the United State, Japan and Canada - the so-called 'Quad') are reviewed very two years; the next 16 largest trading partners every four years; and the remaining Members every six years, with a long interval envisaged for the least-

\footnotetext{
${ }^{1}$ The TPRM was first established at the GATT Secretariat on a trial and error basis in April 1988 as a key accomplishment of the mid-term review of the Uruguay Round. It was subsequently incorporated into the Marrakesh Agreement establishing the World Trade Organisation. Under the GATT the focus of TPRM was limited only to policies and practices governing commodity trade. Under the WTO the focus was extended to cover trade in services and trade related aspects of intellectual property rights. For details on the modalities, operation and the challenges faced by the TPRM see Keesing 1998, Blakehurst 1999 and Laird 1999.
} 
developed countries. By June 2002, a total of 149 reviews had been conducted covering 77 WTO member countries.

As a middle-ranking trading nation, Malaysia is on the four-year review circle. The TPRB concluded its third review of Malaysia during 3-5 December 2001. ${ }^{2}$ The Trade Policy Review: Malaysia 2001 (henceforth referred to as the TPR 2001) provides a comprehensive survey of trade policy making in Malaysia during 1997-2001 in the context of changes in overall economic policy and institutional developments. This is a highly timely publication. It will be valued by the trade policy analysts not only for the purpose of assessing Malaysia's performance in meeting commitments under the WTO Agreement, but also as a essential reference for studying the implications of Malaysia's unorthodox policy response to the recent financial crisis for her long-term commitment to maintaining an open trade and investment policy regimes.

The purpose of this paper is to surveys recent developments in Malaysian trade policy from a historical perspective, using the 2002 TPR review as a reference point. It begins with an overview of Malaysia's economic performance during the postindependence era, paying attention to the underlying political economy (Section 2). This section aims to supplements the background discussion in the TPR 2001on the economic environment and trade policy regimes (Chapters 1 and 2) in providing a framework for assessing recent policy trends. Section 3 ketches out main facets of current trade policy regime, with emphasis on policy shifts following the on-set of the financial crisis. Section 4 provides a critical evaluation of the TPR 2001 in terms of the purpose of the TPRM as set out in Annex 3 of the Marrakesh Agreement (WTO 1995). The final section presents concluding remarks.

\footnotetext{
${ }^{2}$ The two previous reviews were conducted in 1990 and 1996.
} 


\section{TRADE AND DEVELOPMENT IN MALAYSIA: AN OVERVIEW ${ }^{3}$}

Malaysia is considered as one of the great development success stories in the developing world. While Malaysia's economic performance was impressive by developing-country standards over the entire four decades of independence, the achievements were particularly impressive in the decade before the onset of the Asian financial crisis in 1997. During this period Malaysia had one of the highest growth rates (about 9 per cent per annum) in the world (Figure 1). Sustained rapid growth was accompanied by a dramatic decline in the rate of unemployment and rising living standards, and remarkably low inflation. The financial crisis severely disrupted the Malaysian economy and in 1998 real GDP contracted by a staggering 7.5. But, with the help of an unorthodox policy package, which provided for expediting recovery though reflationary macroeconomic policy without deviating from the country's commitment to liberal trade and foreign direct investment policies, the economy recovered quickly, regaining the pre-crisis growth momentum by 2000 .

\section{Figure 1 about here}

\section{(a) Economic Performance}

In the 1970s and early 1980s, the economic expansion in Malaysia was predominantly accounted for by primary sectors. Malaysia's achievements during this period included reaching agricultural food self-sufficiency by the mid-1970s, maintaining its supremacy in the world natural rubber market by remarkable improvement in efficiency of production through a replanting scheme, and reduction in the vulnerability of the plantation sector to vagaries of the world rubber prices by successful diversification into palm oil and coco. From the late 1980s, much of growth has come from the expansion of manufacturing. Between 1987 and 1997, the manufacturing sector grew at an average annual rate of 14 percent, almost double the rate of expansion achieved in the previous ten years. The share of manufacturing in GDP increased from about 20 percent to over 34 percent during this period, contributing to over 50 percent of the increment in GDP.

\footnotetext{
${ }^{3}$ The data used in this section, unless otherwise indicated, come from the Economic Survey, Ministry of Finance, Kuala Lumpur (various issues).
} 
In addition, much of output expansion in the tertiary (service) sectors in recent years has been closely related to the expansion of the manufacturing sector. The share of the agriculture in GDP declined from over 20 per cent in the mid-1980s to less than 9 per cent by the turn of the century, when the economy started to face severe labour shortages (Table 1).

\section{Table 1 about here}

As in the other high performing East Asian countries, rapid export orientation was the whole-mark of industrial transformation in Malaysia. By the mid-1990s, with manufacturing accounting for 80 per cent to total exports of the country, Malaysia had become the sixth largest exporter of manufactured goods in the developing world, after the four Newly Industrialised countries in East Asia (South Korea, Taiwan, Hong Kong and Singapore) and China (WTO 2001). At first, Malaysia's market niches in manufactured exports were in simple assembly operations in electronics and electrical goods, and standards light manufactures such as clothing, footwear and rubber goods. From about the mid-1990s, the export composition began to diversify into mature technology final products such as radios, TVs, cameras and computers. But by the turn of the century semiconductors and other electronics components still accounted for over 45 per cent of total merchandise exports. Most of these 'products' consist of simple assembly operations, although some electronics firms have entered into higher value added fabrication and design activities. From the late 1980s Malaysia has been the largest developing-country exporter (and one of the world's major exporters) of electronic components, particularly integrated circuits. Foreign direct investment (FDI) has played a pivotal role in export-led industrialisation. Foreign firms accounted for over 45 percent of total manufacturing value added and over three-quarters of total manufactured exports by the mid-1990s exports (Athukorala and Menon 1999).

Rapid export-led growth was accompanied by a persistent decline in the unemployment rate, which had reached a peak of $8.5 \%$ by the mid $1980 \mathrm{~s}$. By the mid 1990s the Malaysian economy was at virtual full-employment, with an unemployment rate of only 2.8 percent (Figure 1). The strong expansion of modern sector employment, 
the decline in unemployment and, more recently increasing wages, in turn contributed to reduction of poverty and promotion of equity. The incidence of poverty among all households (as measured by the percentage of total households below the poverty line) fell from 18.4 percent in 1984 to 0.6 percent in 1997. A significant decline was observable for both urban and rural households, even though the incidence of poverty was still relatively high in rural areas. Following the onset of the financial crisis, the unemployment rate rose to $3.3 \%$ in 1998 , but declined to the pre-crisis level by 2000 , without leaving any discernable impact on impressive record of poverty reduction. While less impressive than its record in reducing absolute poverty, Malaysia has also been successful (by the standards of developing countries at the same stage of development) in addressing inequality in the size distribution of income (relative poverty). Between 1970 and 1995, the Gini coefficient fell from 0.51 in 1980 to 0.44 in 1990 and stayed about the same in the ensuing years, suggesting that both the rich and the poor benefited from export-led growth. The quality of life also improved in terms of various indicators. For instance, the literacy rate increased from about 30 in the late 1950s to 90 percent by the turn of the century. In 2000, life expectancy was 70 (up from 40 in the late 1950s), which was only 6 years behind the average for the developed countries. According to the Human Development Index (HDI) of the United Nations - a composite index of literacy, infant mortality and life expectancy - Malaysia ranked fourth (after Saudi Arabia, South Korea and Mauritius) in the world in terms of improvement in living standards in the past three decades (UN 2001).

This performance record looks all the more impressive when viewed against the mixed prognoses of development prospects for Malaysia at independence in 1957 (then the Federation of Malaya). ${ }^{4}$ Of course, Malaysia had some initial advantages such as rich and diversified natural resource endowment, and well-developed infrastructure and an efficient administrative mechanism inherited from the colonial era. Subsequently Malaysia also greatly benefited from it geography, the location in a high growth region. But these non-policy factors were not unique to Malaysia. At the same time, Malaysian

\footnotetext{
${ }^{4}$ In the famous Rosentein-Rodan (1961) growth trajectory up to 1976 for sixty-six of to-days developing countries Malaysia was classified in the 'low-growth' category. A number of other countries newly emerged from the colonial era - in particular India, Pakistan, Ghana, Kenya, and Burma were identified as having much superior growth prospects.
} 
policy makers had to face formidable challenges arising from a pluralistic society characterised by deep ethnic division and unequal distribution of income and wealth along ethnic lines. ${ }^{5}$ The consensus view of various recent prognoses of the Malaysian economic success is that the key to success was sound economic policy (Bhalla and Kharas 1992, Selleh and Meyanathan 1993, Snodgrass 1995, Athukorala and Menon 1999). The Malaysian development policy reflects a unique combination of outwardoriented development strategy ${ }^{6}$ and a comprehensive affirmative action program aimed at maintaining ethnic harmony and social stability.

\section{(b) Policy Trends}

Like in many other developing countries, industrialisation through import substitution was a key emphasis of the Malaysian development strategy in the 1950s and 1960s (Alavi 1996). But Malaysian policy makers, unlike their counterparts in other countries, never resorted to non-tariff protection and direct government involvement in manufacturing through setting up of public sector enterprises as means of 'promoting' industrialisation. Moderate tariff protection was by and large the key instrument used in encouraging new investment in manufacturing. Tariff protection to domestic manufacturing in Malaysia has also been low relative to other developing countries (Power 1971). The role of the government was by and large limited to the provision of conventional public services and implementation of rural development schemes. As already noted, unlike in most other developing countries, there was no direct government involvement in manufacturing though the establishment of state-owned enterprises (SOEs).

Economic expansion during the 1950s and the 1960, although respectable, failed to make a substantial contribution towards solving the "special" problems of the Malays. With urban unemployment rising, and education and language again looming as issues, non-Malays began to question the extent to which their interests were being safeguarded

\footnotetext{
5 At the time of independence, the native Malays, who accounted for 52 percent of the population, were relatively poor and involved mostly in low-productive agricultural activities. The ethnic Chinese (37 percent of the population) enjoyed greater economic power and dominated most of the modern-sector activities.

${ }^{6}$ In a recent comprehensive study of the patterns and chronology of trade policy reforms during the postwar era, Sachs and Warner (1995, Table 1) identify Malaysia as one of the eight developing countries whose trade regimes remained open throughout the post-Second World War period.
} 
in the new Malaysia. The disenchantment growing among all segments of the population ultimately erupted in the bloody communal riots of 13 May 1969. This event gave birth to a weeping affirmative action policy, the New Economic Policy (NEP), which came into effect in 1970 (later modified and renamed National Development Policy, NDP, in 1990) (Leigh 1992, Snodgrass 1995). The overriding objective of NEP was to maintain national unity through the pursuance of two objectives: eradication of poverty among the entire population and restructuring of the Malaysian society so that the identification of race with economic function and geographical location is reduced. These objectives were to be ached through a wide range of direct redistribution polices including privileged access to subsidised credits, modern sector employment, and share ownership in private enterprises for the native Malays (Bumiputra). But the resource cost of these direct redistribution policies was not a major drag on growth because the government continued to maintain an outward oriented overall policy stance. Given that the trade and foreign investment regimes continued to remain open, and the government by and large continued to maintain its firm commitment to basic rules of 'good governance' (in particular maintaining macroeconomic stability, developing economic infrastructure, and preserving private property rights) there was ample room for the private sector to expand through greater integration in the global economy.

There was a heavy emphasis on the promotion of heavy industries through direct government involvement in the first half of 1980s, as part of the 'look East' policy of Dr Mahathir who became Prime Minister in 1981 (Chee 1994). The Heavy Industries Corporation of Malaysia (HICOM), a public-sector holding company, was formed in 1980 to go into partnership with foreign companies in setting up industries in areas such as petrochemicals; iron and steel; cement; paper and paper products; machinery and equipment; general engineering; transport equipment; and building materials. The symbol of the selective industrial policy was the Proton (the Malaysian national car) project, which was set up by HICOM in collaboration with the Mitsubishi Corporation in Japan. By 1987, there were 867 corporate public enterprises in Malaysia, more than a third of which were in manufacturing. Tariffs on a wide range of manufactured goods were increased in the first half of 1980s as part of the heavy-industrialisation move. But there was no significant reliance of quantitative import restrictions; only 8 percent of total 
merchandise imports (on an import-weighted basis) were under such restrictions by the mod-1980s (Menon 1999, Table 1). By the mid-1990s, only 3 percent of all import tariff lines (accounting for about 4.5 per cent of annual import value) were subject to licensing requirements.

The economic crisis during 1985-87, which originated in a combination of budget deficits caused by the heavy industrialisation move and adverse trends in prices of Malaysia's major export products (Corden 1996), put an end to the state-led heavy industrialisation push. The crisis management policy package placed greater emphasis on the role of the private sector and strengthening the conditions for export-oriented industrialisation through greater participation of FDI. The structural adjustment reform package introduced in response to the crisis involved a gradual process of privatisation and restructuring of state-owned enterprises. By the early 1990s state-ownership in manufacturing was limited only to some politically sensitive ventures in automobile manufacturing (the Proton project), petrochemical, iron and steel and cement industries (Kanapathy 2000). The Promotion of Investment Act of 1986 introduced fresh, more generous incentives for private investors, and some of the ethnic requirements on company ownership of the NEP were relaxed. The reforms after the mid-1980s also involved significant tariff reductions and removal of quantitative import restrictions ${ }^{7}$, removing restrictions on foreign portfolio investment in the country, a gradual process of privatisation and restructuring of state-owned enterprises and labour market reforms to make Malaysia more cost-competitive as a location of international production.

In the early 1990s, Prime Minister Mahathir came up with a policy blueprint (the Vision 2020 Statement) for transforming Malaysia to developed-country status by the year 2020. ${ }^{8}$ Most of these proposals - in particular those relating to the provision of infrastructure, maintaining macroeconomic stability, human capital development and commitment to a more equitable distribution of fruits of economic growth - simply

\footnotetext{
7 The economy-wide import-weighted tariff rate declined from 14.7 during 1984-87 to 8.7 per cent by the mid-1990s, the lowest in Southeast and South Asia (Menon 2000, Table 1; ADB 1997 p. 96). By the mid-1990s, only 3 percent of all import tariff lines (accounting for about 4.5 per cent of annual import value) were subject to licensing requirements.

${ }^{8}$ Government programs and procedures for achieving these goals were embodied in the Seventh Malaysia Plan (1996-2000) and the Second Industrial Master Plan released in 1996.
} 
reconfirm the long-standing commitment of the Malaysian government to good governance. However, the new policy also introduced a plethora of new incentives geared to industrial upgrading and strengthening domestic linkages of the manufacturing sectors, which opened up new opportunities for policy-maker desecration. However, the long-standing commitment to private-sector oriented growth in the context of an open trade and investment regime continued to remain the basic tenet of Malaysia's national development strategy.

\section{(c) Policy Response to the Financial Crisis}

The impressive growth trajectory of Malaysia was shattered by the currency crisis in late 1997. The currency and stock market turmoil that began in July 1997 was quickly translated into economic collapse.

Unlike the other three crisis countries, Malaysia succumbed to the crisis with only a little foreign debt exposure of its banking system. For this reason, the Malaysian policy markers were able to face the crisis without entering into an IMF-sponsored rescue package. However, for almost one-and-a-half years following the onset of the crisis, policy indecisiveness seriously hampered the recovery process. It was difficult for the Malaysian authorities to mobilise foreign financing for crisis management because of the market perception that Malaysia would be less committed to the required reforms since it was not under an IMF program. To make matters worse, the massive private sector domestic bank debts in the lead-up to the crisis $^{9}$, constrained the use the interest rate policy to support the exchange rate in face of continuing capital outflow. By mid-1998, the economy was in its worst recession during the post-independence era and there were no signs of achieving currency and share price stability.

In this volatile economic climate, the Malaysian government had to choose between two alternatives. The first was to obtain a 'good housekeeping seal' on its policies from the IMF. This would, like in Korea and Thailand, have stabilized the exchange rate, setting the stage for applying the Keynesian therapy to speed up the

\footnotetext{
${ }^{9}$ At the time Malaysia had by far the largest bank credit to GDP ratio (165\%) among the crisishit Asian countries (and in the world at large).
} 
recovery. The second option was to embark on a capital-control based macroeconomic stimulation package; to insulate the domestic financial markets from short-term financial flows through capital controls with a view to enabling vigorous pursuance of monetary and fiscal expansion, and undertaking banking and corporate restructuring. The first alternative was not politically acceptable to the Malaysian leadership. Given the intimate links developed between business and government under the NEP program, naturally the positive stabilizing impact of any policy move had to be weighed against its potential negative effect on socio-political stability of the country (Crouch 1998). Thus the Malaysian leadership opted for the second alternative, ending the policy uncertainty that had pervaded the policy scene for almost a year.

The purpose of capital outflow controls in the new policy package was to make it harder for short-term portfolio investors and offshore hedge funds to drive down the currency. Thus these controls were confined to short-term capital flows only. With the exception of limits on foreign exchange for foreign travel by Malaysian citizens, there was no retreat from the country's long-standing commitment to an open trade and investment policy. Profit remittances and repatriation of capital related to FDI in the country continued to remain free of control. Moreover, some new measures were introduced to further encourage FDI participation in the economy. These included allowing 100\% foreign ownership of new investment made before 31 December 2000 in domestic manufacturing regardless of the degree of export orientation; increasing the foreign ownership share in the telecommunication project from $30 \%$ to $69 \%$ (under the condition that the ownership share is brought down to $49 \%$ after five years), and in stockbroking companies and insurance sector from a previous uniform level of $30 \%$ to $49 \%$ and $51 \%$ respectively; and relaxing restrictions on foreign investment in landed property to allow foreigners to purchase all types of properties above RM 250,000 in new projects or projects which are less than $50 \%$ completed.

1998 Budget speech unveiled on 17 October, Import duties on automobiles, vans and motorcycles were increased from 30-200\% to 40-300\% for CBU (completely builtup) and $4-42 \%$ to $30-80 \%$ for CKD (completely knocked down) and construction equipment from $0-35 \%$ to $5-50 \%$. In addition a number of heavy and construction 
equipment, hot and cold rolled flat products of iron or non-alloy steel, ephedrine and its salts, chemical products, certain electrical household goods were brought under nonautomatic import licensing. The declared purpose of these measures was to bring down the current account deficit, but cushioning local producers (including the national car producer, Proton) against domestic demand contraction was obviously a key motivating factor.

The Malaysian economy began to recover from its worst recession during the post-independence era for about the second quarter of 1999. By mid-2000 the economy was back to the post-crisis output level. Although the expansion of export-oriented industries aided by the recovery in the global electronics industry played an important role, the recovery was not entirely export-led. Domestic demand expansion triggered by expansionary macroeconomic policy played a pivotal role in achieving a broad-based recovery. Moreover, the fixed exchange rate is belied to have helped the recovery process by preventing premature exchange rate appreciation as part of improved market sentiments about the recovery prospects. Capital controls also assisted banking and corporate restructuring by facilitating the mobilization of domestic resources, and more importantly, providing a cushion against adverse market sentiments of improper practices of protecting favoured companies and corporations (Athukorala 2001, Corden 2002). 


\section{CURRENT TRADE POLICIES AND PRACTICES}

This section provides a broad-brush picture of the current trade policy regime in Malaysia drawing upon TPR 2001 and supplementing it with additional information for comparing the Malaysian experience with that of the other major economies in the region. Following the format of the TPR we first discuss the broad sweep of trade policy focussing on the key instruments (measures), followed by a discussion of sectoral policies.

a. $\quad$ Trade Policies and Practices by Measure

(i) Import Tariffs

As already noted, tariffs have continued to be the main border measure affecting Malaysia's import trade throughout the post-independence period. The current tariff structure (as of end 2001) contains 10,368 tariff lines (9-digit HS level) and involves 73 different rates. As a result of the conversion of some specific, compound, and alternative duties into ad valorem rates following the singeing of the WTO Agreement in 1995, the share of total lines with non-ad-valorem tariffs declined from $4.5 \%$ of tariff lines in 1997 to only $0.7 \%$ in 2001 . There are no tariff quotas or variable import levies.

The tariff increases introduced in 1998 (see above) have resulted in a mild, yet notable, reversal in the declining trend in the average nominal tariff rate maimed from the mid 1980s (Menon 2000, Table 1). The average applied MFN tariff increased from $8.1 \%$ in 1997 to $9.2 \%$ in 2001 (Table 2). Average level of nominal tariff protection is lower than that indicated by the simple average applied MNF average owing to various tariff concessions, often for capital and intermediate inputs, as well as preferential rates, particularly those favouring ASEAN countries under AFTA. The ration of actual import duty collected to total value of merchandise imports (the implicit nominal duty rate) in fact declined from $3 \%$ in 1997 to $1.3 \%$ in 2000.

\section{Table 2 about here}

The degree of dispersion tariff rates measured by the coefficient of variation increased from $91 \%$ in 1988 to $170 \%$ in 1997 and then to $210 \%$ in 2001 , reflecting the 
increase in the number of tariff lines with rates less than $10 \%$ and higher than $20 \%$ (Table 2). By contrast, domestic tariff peaks (lines with tariff rates exceeding three times the simple average tariff rate as a percentage of total tariff lines) have declined. Tariff peaks apply, inter alia, to automobiles, beverages, textiles and clothing.

Malaysia bound only $65 \%$ of its tariff lines in 1995 and the bound list has remained unchanged during the ensuing years. Moreover the bound rates are much higher than the applied MFN rates. Both these features of the tariff structure have provides the government with scope to raise applied tariffs (as was done in 1998), imparting a degree of uncertainty to applied tariffs.

The increases in nominal tariff rates in recent years have largely been confined to products in final stage of processing (Table 2). Nearly $60 \%$ of total tariff lines, which relate mostly to inputs to domestic industry (that is, products in the first stage of processing and the semi-process products) continued to remain duty free. A large number of dutiable imported inputs also benefited from some tariff reductions. This cascading pattern of the tariff structure implies that the effective rate of protection enjoyed by domestic manufacturing would have considerably increased during the review period.

Malaysia is a founding member of the Association of the South East Asian nations (ASEAN) and the ASEAN Free Trade Agreement (AFTA). Malaysia has agreed to provide tariff preferences to the AFTA member countries on 8,764 tariff lines under the Common Effective Preferential Tariff (CEPT) scheme of AFTA. Tariffs on these product lines are to be reduced to a range of 0 to $5 \%$ by the end of 2002. Starting in 1993, Malaysia has progressively placed $96 \%$ of the agreed tariff lines under the CEPT scheme. To date, $96 \%$ of Malaysia's tariff lines have been transferred to the CEPT scheme. Two thirds of these tariff lines are duty free. Malaysia has obtained AFTA approval for not including automobile products (218 tariff lines) into CEPT scheme until 2005 in view of the difficulties faced by the domestic automobile industry. Tariff preferences granted under the CEPT scheme are subject to the fulfilment of rules of origin criteria, which have been set at minimum $40 \%$ local or regional value added. 
In addition to the tariff preferences granted under the CEPT scheme, Malaysia provides the other five original member countries of the $\mathrm{ASEAN}^{10}$ tariff preferences under ASEAN Preferential Trading Agreement (APTA) signed in 1997. APTA cover all products that are not included in the CEPT scheme and the preferential rates are $50 \%$ to 100\% lower than the respective MFN rates. Between 1997 and 2001, the simple average of AFTA tariff decreased from $4.7 \%$ to $3.9 \%$, as against an increase in the average MFN rate from rose from $8.1 \%$ to $9.2 \%$.

The widening gap between the average MFN tariffs and the significant tariff preferences granted under the CEPT and APTA schemes, coupled with the widening gap between APTA and MFN rates, have set the stage for potential diversion of Malaysia's trade from non-AFTA trading partners to AFTA countries. No systematic study of such trade diversion has yet been undertaken. The share of imports from AFTA countries in total imports of Malaysia increased from 18\% to over 23\% between 1996 and 1999, but this increase cannot be ascribed to trade diversion alone. Various other factors, including the significant depreciation of ASEAN currencies against non-ASEAN currencies in the wake of the Asian financial crisis and the growing important intra-regional cross-border trade in components in within vertically integrated manufacturing production (in particular electronics and motor vehicle industries) many have contributed increase in intra-regional trade.

Table 3 compares Malaysia's tariff structure in 2000 (the latest year for with comparable data are available) with that of the major trading nations in the region. Despite recent tariff increases Malaysia's average tariff rate is relatively low (both in terms of the simple average and import-weighted average) by the regional standards. However, the degree of dispersion of tariff in Malaysia (measured by the coefficient of variation) is relatively high because of high tariff peaks relating to a few product lines, motor vehicles in particular.

\footnotetext{
${ }^{10}$ Indonesia, the Philippines, Singapore, Thailand and Brunei.
} 


\section{Table 3 about here}

\section{(ii) Non-tariff Barriers (NTBs)}

There are no import quotas in Malaysia and the existing import prohibitions are limited only to those implemented for national security reasons. However, some agricultural and industrial products have continued to remain under import licensing. As noted, following the onset of the recent financial crisis the licensing list was widen to cover a number of heavy and construction equipment, iron and steel products, industrial chemicals and certain electrical household goods. Consequently, the number of tariff lines subject to a non-automatic import licensing requirements increased from $17 \%$ in 1996 to $27.3 \%$ in 1997 (WTO 2002, P 39). The import restraining effect of these controls are not known, but there is circumstantial evidence that the degree of restrictiveness involved in the licensing process has increased following the onset of the crisis.

In 1998 and 1999, Malaysia revised its anti-dumping and countervailing legislation with a view to bringing it into conformity with the WTO agreement on Subsidies and Countervailing Measures. But unlike many other WTO member countries, Malaysia has not relied heavily on contingent measures for controlling imports; during 1997-2001 Malaysia initiated only five anti-dumping investigations (of which three were provisional measures). ${ }^{11}$ Currently there is no safeguard legislation in Malaysia.

As part of commitments of the WTO agreement on Trade Related Investment Measures (TRIMS), Malaysia abolished all local content requirements measures on 31 December 2000, except those in the motor vehicle sector. Malaysia requested an extension of the transition period until 2005 for eliminating local-content requirements in the automobile sector as a condition for establishing a new industry. In compliance with the Agreement on Trade Related Intellectual Property Rights (TRIPs), Malaysia has enacted two new legislation (the Layout Design of Integrated Circuits Act 2000 and the Geographical Indications Act 2000) and has amended the Patents Act 1983, Trade Marks

\footnotetext{
${ }^{11}$ Total number of antidumping cases notified by the member countries to the WTO in 1999 amounted to 360, up from 150 in 1998.
} 
Act 1976, the Copyright Act 1987, and the Industrial Designs Act 1996 (WTO 2002 p. 19).

Malaysia is not a party to the Agreement on Government Procurement (GPA), though it does participate in the WTO working group on transparency in government procurement. Government procurement procedures in Malaysia, notably preferential margins, tend to favour locally owned businesses, particularly where relatively small amounts are involved. Foreign suppliers are usually excluded for contracts of large amounts unless the supplies or services are not available locally; foreign contractors are allowed to participate if there is no local expertise. It eliminated other local-content requirements tied to investment incentives. There are no non-preferential rules of origin impacting on imports.

(iii) Export Taxes and Subsidies

Some primary products, notable forest products, crude oil, and selected palm oil products are subject to export duties. In 2000 these duties contributed to about $2 \%$ tax revenues. A few agricultural products are also subject to prohibitions, restraints, and licensing requirements.

There are no export duties on manufactured products. On the contrary, assistance is provided to manufactured exports through import tariff concessions, tax exceptions, export credit, export insurance and export credit guarantees, export promotion and marketing assistance. In addition Malaysia maintains two types of facilities for export processing with minimum customs formalities; licensed manufacturing warehouses and free zones. Malaysia is committed to phasing out these export subsidies in the manufacturing sector over eight years, to bring them in conformity with the WTO Agreement.

(iv) Other Measures affecting production and trade

Over the past five years, Malaysia has taken initiatives to gradually bring domestic product standards into line with international norms. About $31 \%$ of the 2,862 Malaysian 
standards currently in force are aligned with or based on international standards. But $80 \%$ of the new standards developed by Malaysia in 1998 and 1999 correspond to international standards. During the period under review, Malaysia enacted two new laws and amended four others to strengthen the protection of intellectual property rights and bring domestic legislation into conformity with the TRIP Agreement. It has also stepped up enforcement of IPR laws, especially those pertaining to copyrights.

The government has a privatisation program dating back to 1987. But state-owned enterprises still continue to play an important role in the economy. As of 2000 there were 37 state-owned enterprises or non-financial public enterprises (NFPEs) involved in manufacturing, mining and petroleum, and services sector (electricity, transportation, telecommunications, and postal activities). The development expenditure by NFPEs represented more than 50\% of total public state expenditure during the period 1996-2000. (WTO, 2002, p 65). Apart from their own operations, some of these enterprises provide finance not just to each other, but also to private companies. State owned enterprises play an important role in the Malaysian economy, especially in petroleum, transport, telecommunication, postal and electricity industries. In December 2000, 40 companies in which the State has substantial share represented 5\% of companies listed on the Kuala Lumpur Stock Exchange and they accounted for $30.3 \%$ of the total market capitalisation of all listed companies.

Malaysia does not have a comprehensive competition law or other laws that regulate the activities of enterprises and protect consumer interest. However, the government has recently established some competition guidelines with a view to fostering competition in telecommunications. As part of corporate restructuring following the on-set of the crisis, the government also has taken some initiatives to improve corporate governance in Malaysia, including introducing disclosure requirements and monitoring insider share trading.

\section{(b) Trade Policy by Sector}


At the sectoral level, overall Malaysia maintains liberal agricultural policies, especially as far as non-tariff border measures are concerned. Generally speaking, import tariffs on agricultural products (HS chapters 01-24) are low, averaging 0.5\% in 2001, if non-ad valorem duties are excluded. However, a wide range of agricultural imports is subject to import licensing.

Non-border measures, notably production subsides are also used to support domestic (non-plantation) agriculture. The total government outlay on these support measures amounted to RM 995 million in 1998 (the latest year for which data are available). The rice sector stands out as the single most assisted agricultural activity. The government assists rice producers with a comprehensive fertilizer subsidy, a guaranteed minimum price and a price subsidy scheme. Poverty reduction and food security are often cited as the main rationale behind such policy. Under the guaranteed minimum price scheme, BERNAS (a privatised enterprise involved in state trading) undertakes to buy paddy from farmers at not less than the guaranteed minimum prices. Under the paddy price subsidy scheme, the government makes fixed payments to farmers for the paddy sold by them to any commercial rice mills. Total expenditure in 1998 on the three schemes amounted to RM 547 million (US\$ 150) or nearly 55\% total production subsidies.

Import tariffs on mining products (including crude petroleum and gas) were eliminated in 1997. They are not subject to any import restrictions, except for barite, which requires import licence. Currently there is no export duty on petroleum products; while exports of crude oil and tin are subject to export duties at $10 \%$ and $0-25 \%$, respectively.

The wholly state-owned company, PERTONAS (established under the Petroleum Development Act 1974) continues to be the main vehicle for the appropriation of resource rents from oil and gas; it has exclusive rights of ownership, exploration and production, and is responsible for planning, investment, and regulation of all activities relating to exploration of petroleum products. Foreign investment or participation in the upstream industry (processing and refining of petroleum and the manufacture of 
petrochemical products) is accepted in the form of production-sharing contracts (PSC); by the end of 2000, PETRONAS had signed more that 60 PSCs with foreign companies. Foreign equity participation up to $100 \%$ is permitted in the mining sector depending on the level of investments, technology and risk involved in the project, the availability of Malaysian expertise in the exploration and mining, and the level of domestic value added.

The total number of duty free import lines relating to manufactured imports increased from 4155 to 4336 between 1997 and 2001. Tariffs on selected manufactured goods have been reduced either on unilateral basis or under the WTO commitments. However the average tariff rate for manufactured imports increased from $6.4 \%$ to $8.2 \%$ because of increases in tariffs on automobiles, construction equipment, certain appliances and alcoholic beverages in 1998. As already noted, a number of manufactured goods are also subject to discretionary import licensing for public health, security as well as for protection purposes. Exports of manufactured products enjoy virtual free trade status through export duty exemptions, duty drawback facilities and free trade zone status. Exports are also exempted from sales tax.

Heavy protection given to automobile industry remains a major anomaly in Malaysia's structure of industrial protection. The domestic automobile market is protected through both tariff and non-tariff measures. Following the latest increases in October 1997, currently automobile tariff range from $42 \%$ to $80 \%$ on completely knocked down (CKD) cars, and from $140 \%$ to $300 \%$ on completely built up (CBU) cars. Most automobile parts and components, except tractor parts (duty free) are subject to 25-30\% tariffs. Motor vehicles, chassis fitted with engine for automobiles and motor vehicles, chassis not fitted with engine and parts thereof, bodies for ambulances, and road tractors for semi-trailers are subject to discretionary import licensing. A number of internal taxes, such as tax sales tax at $10 \%$, exercise tax at various rates, and road taxes based on engine capacity are imposed on all vehicles. The national cars, Proton and Perodua, receive 50\% reduction in exercise tax. All assemblers and manufacturers including the two national car companies must source certain percentage of parts and components locally (WTO 2002, p. 77). The Given heavy protection; domestic production naturally accounts for the lions' share (over 90\%) of the domestic car market. 
Despite various export incentives offered, exports of automobile products accounted for a mere $0.4 \%$ of total merchandise exports in 1999 (WTO 2002, p. 75).

Until 1998 full foreign ownership was allowed only in export-oriented manufacturing ventures. As part of new incentives offered for foreign investors following the onset of the financial crisis full foreign equity participation was allowed for newly approved on or before December 2000 (subsequently extended to December 2003). However, activities that involve small and medium-sized enterprises, like paper packaging, plastic packaging, metal stamping and fabrication, wire harness, and printing excluded from this relaxation. Foreign equity participation in these industries is limited to $30 \%$ if the products are domestic-market oriented.

The services sector, which accounts for over half of GDP, is not as open to trade as agriculture and manufacturing. Foreign commercial presence is generally confined to joint ventures in which combined foreign ownership cannot normally exceed $30 \%$. The Malaysian government has already signed the Information Technology Agreement and the Fourth and Fifth Protocols of the General Agreement on Trade in Services (GATS) concerning basic telecommunication services and financial services respectively. But the progress with implementing the proposed reforms has much slower than anticipated. 


\section{ASSESSING THE REVIEW}

Like the two previous reviews, the TPR 2001 is a useful basic source of information on recent changes and the current state of trade and foreign investment policies and the related domestic polices in Malaysia. The report is particularly commendable given the severe staffing and financial constraints under which the WTO Secretariat operates (Keesing 1998, Blackhurst 1998). There are, however, many areas in which more analysis could have been done.

As number of participants of the TPRB meetings have indicated the discussion on the capital-control based recovery package introduced in October 1998 is rather sketchy and does not provides a balance treatment of various opinions about role in speeding up the recovery process. The authors of the Review seems to support the view that the imposition of controls on capital outflow by the Malaysian government was simply $a$ ritualistic locking of the barn door after the horse was stolen. This is a misleading view because the purpose of controls was to set the stage for monetary expansion by preventing outflow of funds, both local and foreign-owned (particularly the former given that much of the short-term capital had already left the country), in response to lowering of domestic interest rate relative to world market rates. The potential threat of such outflow was much greater in Malaysia than in the other crisis-hit countries because of the pivotal role played by the Singapore money market as a convenient alternative to the domestic market for the Malaysian investor.

There is evidence that, once the Malaysian authorities decided to deviate from the IMF route and followed the conventional Keynesian recipe for crisis management, capital controls did play a useful role in providing a conducive setting for the effective pursuance of such policies. Against the popular perception that short-term capital flows cannot be controlled in a highly trade oriented economy, the Malaysian evidence suggests these flows can be effectively regulated (at least on the margin), provided the controls are specifically targeted at capital account transactions (Ito 2000, Athukorala 2001, Corden 2002). One can still disputes the argument that controls have played a 'special role' in delivering a superior recovery outcome for Malaysia (compared to the IMF-program 
countries) for want of counterfactuals. However, the fact remains that the new policy measures enabled Malaysia to achieve recovery while minimising social costs and economic disruptions associated with a more market-oriented path to reform. This itself is a significant achievement because maintaining social harmony is an overriding concern (quite apart from economic efficiency consideration) of economic policy making in ethically diverse Malaysia (Crouch 1998).

The bulk of the discussion on the structure of trade protection in the TPR 2001 is on tariff barriers. In most cases the discussion on non-tariff barriers has not gone beyond a simple listing of the instruments and the commodities covered. For instance, it points to the recent increase in the reliance on import licensing, but there is little discussion of implications of these increases for Malaysia import trade and relative incentives for domestic industries. It is mentioned that licensing is 'non-automatic' without providing any evidence about the extent to which the administrative discretion is used to regulate trade flows. A close look at the commodity coverage of licensing suggests that a significant number of these products directly compete with domestic production by publici sector enterprises. It could well be that licensing is used in a more restrictive manner in these areas to protect government monopolies at the expense of the private sector.

It is reported that so far Malaysia has by and large shunned the use of antidumping procedures to as a new form of import protection. At first look, this is indeed a positive development. But it could well be that there is no need to rely on antidumping or other contingency measures as discretionary licensing act as a more effective (hidden) tool of protection in the hand of the Malaysian authorities.

Another important element of trade and industry policy that has not received due attention is export subsidies. Judging from the listing of various export subsidies in the Review, despite Malaysia's remarkable export success over the past two decades, still export subsidies are an important item in the incentive structure. To what extent have these subsidies been important in explaining the 'export success'? Has it been based primarily on sound economic fundamentals, while subsidies simply taking the form of 
unnecessary, costly transfers from the government to the export sectors? Answering these and related questions is important in assessing the implications of promised dismantling of export subsidies for Malaysia's future growth prospects.

Finally, the TPR has paid little attention to implications of Malaysia's trade policy for global trading system, even though this has been listed in the Marrakesh Agreement as an important aspect of national trade and investment policy to be review under the TPRM. An important subject, which should have received attention in this connection, is the possible trade diversion effect of trade preferences under the CEPT scheme of the AFTA. Another important related development that has been completely ignored in the Review is the recent expansion of outward foreign direct investment from Malaysia.

\section{CONCLUSION}

The Trade Policy Review: Malaysia 2001 is a valuable source of information for studying recent developments and the current state of trade and investment policy in Malaysia. However, its subject coverage is rather lopsided. Much of the Review is about tariffs. The discussion on various non-tariff barriers (in particular non-discretionary licensing, which seems to have gained in importance in recent years), government procurement practices, export subsidies and agricultural production subsidies has not gone beyond providing a chronology of events and listing of policies. The overall discussion on recent policy changes in the TPR provides some clues about some notable deviation of Malaysia's trade policy stance from the country's pre-crisis commitment to trade liberalisation. But no attempt has been made to highlight these deviations, let alone analysing their socio-political underpinnings and economic implications. Nor is there any substantial assessment of the problems faced by Malaysia in meeting its remaining commitments under the WTO. 


\section{References}

Alavi, R. (1996), Industrialisation in Malaysia: Import Substitution and Infant Industry Performance, London: Routledge.

Athukorala, P. and J. Menon (1999), 'Outward Orientation and Economic Development in Malaysia', World Economy, 22 (8), 1119-1139.

Athukorala, P. (2001), Crisis and Recovery in Malaysia: The Role of Capital Controls, Cheltenham: Edward Elgar.

ADB (Asian Development Bank) (1997) Emerging Asia: Changes and Challenges, Manila: ADB.

Bhalla, S. and H. Kharas (1992), Growth and Equity in Malaysia: Policies and Consequences', in The Hoe Yoke and Goh Kim Leng (eds), Malaysia's Economic Vision: Issues and Challenges, Kuala Lumpur: Pelanduk Publications, 41-88.

Blackhurst, R.(1998), 'The Capacity of the WTO to Fulfil Its Mandate', in A.O. Krueger (ed.), The WTO as an International Ornagization, New York: Oxford University Press, 31-58.

Chee P. L. (1994), “Heavy Industrialisation: A Second Round of Import Substitution”, in Jomo, K.S. (ed.), Japan and Malaysian Development in the Shadow of the Rising Sun, London: Routledge, 244-62.

Corden, W. M. (1996), Pragmatic Orthodoxy: Macroeconomic Policies in Seven East Asian Economies, San Francisco: International Center for Economic Growth.

Corden W. M.(2002), Too Sensational: On the Choice of Exchange Rate Regimes, Cambridge, Mass.: MIT Press.

Crouch, H. (1998) 'The Asian Economic Crisis and Democracy', Public Policy, 11(3): 39-62.

Ito, Takatoshi (2000), Capital Flows in Asia', in Sebastian Edwards (ed.), Capital Flows and the Emerging Economies: Theory, Evidence and Controversies, Chicago: University of Chicago Press, pp. 255-297.

Kanapathy, V. (2000), 'Industrial Restructuring in Malaysia: Policy Shifts and the Promotion of New Sources of Growth', in Seiichi Masuyama, Donna Vandebrink 
and Chia Siow Yue (eds), Industrial Restructuring in East Asia, Singapore: Institute of Southeast Asian Studies, 139-165.

Keesing, D. B. (1998), Improving Trade Policy Reviews in the World Trade Organization, Washington, DC: Institute for International Economics

Laird, S. (1999), 'The WTO's Trade Policy Review Mechanism: From Through the Looking Glass', World Economy, 22(6), 741-764.

Leigh, Michael (1992), "Politics, Bureaucracy, and Business in Malaysia: Realigning the Eternal Triangle", in Andrew J. MacIntyre and Kanishka Jayasuriya (eds.), The Dynamics of Economic Policy Reforms in South-east Asia and the South-west Pacific, Singapore: Oxford University Press, 115-137.

Menon, J. (2000), 'How Open is Malaysia? An Analysis of Trade, Capital and Labour Flows', World Economy, 25(2), 235-256.

Power, John H. (1971), 'Structure of Protection in West Malaysia', in Bela Balassa (ed.), The Structure of Protection in Developing Countries, Baltomore, MD: Johns Hopkins University Press.

Rosentein-Rodan, P. (1961), 'International Aid for Underdeveloped Countries', Review of Economics and Statistics, 43(2), 107-38.

Salleh, I. M.. and S. D. Meyanathan (1993), Malaysia: Growth, Equity, and Structural Transformation, Washington DC: World Bank.

Sachs, J.D. and Warner, A. (1995) 'Economic Reforms and the Process of Global Integration', Brookings Papers on Economic Activity, 25th Anniversary Issue: $1-95$.

Snodgrass, D. R. (1995) 'Successful Economic Development in a Multi-ethnic Society: The Malaysian Case', Development Discussion paper No. 503, Harvard Institute for International development, Harvard University.

UN (United Nations) (2001), Human Development Report 2001, New York: Human Development Report Office.

WTO (World Trade Organization), (1995), The Results of the Uruguay Round of Multilateral Trade Negotiations: The Legal Text, Geneva: WTO.

WTO (World Trade Organization), (1998) Trade Policy Review: Malaysia 1997, Geneva: WTO.

WTO (World Trade Organization) (2001), Annual Report 2001, Geneva; WTO. 
WTO (World Trade Organization), (2002) Trade Policy Review: Malaysia 2001, Geneva: WTO. 
Table 1: Malaysia: Sectoral Growth Performance

\begin{tabular}{|c|c|c|c|c|c|c|c|c|c|}
\hline & 1970 & 1975 & \multicolumn{2}{|c|}{1980} & \multicolumn{2}{|l|}{1985} & & 1997 & 2000 \\
\hline \multicolumn{10}{|l|}{ (a) Composition (\%) } \\
\hline Agriculture & 28.5 & 26.9 & \multicolumn{2}{|c|}{22.9} & 20.8 & \multicolumn{2}{|c|}{18.7} & 12.6 & 8.8 \\
\hline Industry & 32.3 & 32.6 & \multicolumn{2}{|c|}{35.8} & 36.7 & \multicolumn{2}{|c|}{42.2} & 41.3 & 46.3 \\
\hline Manufacturing & 15.8 & 17.3 & \multicolumn{2}{|c|}{19.6} & 19.5 & \multicolumn{2}{|c|}{26.9} & 34.2 & 32.6 \\
\hline Services** & 33.5 & 40.5 & \multicolumn{2}{|c|}{41.3} & 42.6 & & & 38.9 & 44.9 \\
\hline GDP & 100 & 100 & \multicolumn{2}{|c|}{100} & 100 & & & 100 & 100 \\
\hline \multicolumn{2}{|l|}{ (b) Average annual growth (\%) } & \multicolumn{8}{|c|}{$1970-75$ 1975-80 1980-85 1985-90 1990-97 $1997-2000$} \\
\hline Agriculture & & \multicolumn{2}{|c|}{9.5} & \multicolumn{2}{|c|}{5.1} & 3.1 & 4.6 & 2.4 & -0.9 \\
\hline Industry & & \multicolumn{2}{|c|}{6.7} & \multicolumn{2}{|c|}{10.7} & 5.7 & 9.8 & 12.8 & 2.1 \\
\hline Manufacturing & & \multicolumn{2}{|c|}{6.7} & \multicolumn{2}{|c|}{11.4} & 5.3 & 13.7 & 13.2 & 5.7 \\
\hline Services** & & \multicolumn{2}{|c|}{12.2} & \multicolumn{2}{|c|}{13.9} & 5.8 & 5.1 & 10.2 & 1.5 \\
\hline GDP & & \multicolumn{2}{|c|}{10.6} & 8.5 & & 5.2 & 6.8 & 8.1 & 2 \\
\hline
\end{tabular}

Notes: * Output shares and growth rates are based on constant (1978) prices. Growth rates are annual averages between the reported years.

** Include import duties net of bank service charges.

Source: Ministry of Finance Malaysia, Economic Report (various issues) 
Table 2: Tariff Structure of Malaysia (MFN Tariff)

\begin{tabular}{|c|c|c|c|c|}
\hline & 1988 & 1993 & 1997 & 2001 \\
\hline Number of tariff lines & 12,183 & 11,875 & 10,372 & 10,368 \\
\hline Bound tariff lines ${ }^{1}(\%)$ & 0.8 & 0.8 & 63.7 & 63.5 \\
\hline Duty-free tariff lines ${ }^{1}(\%)$ & 10.3 & 13.4 & 58.6 & 58.3 \\
\hline Specific and mixed tariffs ${ }^{1}(\%)$ & 22.2 & 12.0 & 4.5 & 0.7 \\
\hline Tariffs with no ad valorem equivalent ${ }^{1}(\%)$ & 7.4 & 5.9 & 4.5 & 0.7 \\
\hline Simple average applied rate $(\%)$ & 17.5 & 15.2 & 8.1 & 9.2 \\
\hline Agriculture (HS 01-24) & 7.7 & 7.3 & 4.8 & 3.5 \\
\hline Industrial products (HS 25-93) & 14.8 & 14.7 & 8.5 & 9.9 \\
\hline Tariff range $(\%)$ & $0-207.5$ & $0-140$ & $0-200$ & $0-300$ \\
\hline Import weighted average $(\%)$ & 15.5 & 11.9 & 9.9 & \\
\hline Domestic tariff peaks ${ }^{2}(\%)$ & 0.8 & 2.2 & 15.8 & 9.6 \\
\hline International tariff peaks ${ }^{3}(\%)$ & 51.3 & 49.1 & 25.9 & 23.8 \\
\hline Coefficient of variation (\%) & 91 & 86 & 170 & 210 \\
\hline \multicolumn{5}{|l|}{ Simple average tariff by stage of processing (\% } \\
\hline Raw materials & 14.6 & 14.3 & 1.0 & 0.9 \\
\hline Agricultural products & 16.9 & 16.5 & 0.6 & 0.5 \\
\hline Mining products & 3.6 & 3.8 & 1.0 & 1.0 \\
\hline Manufactured products & 5.9 & 5.8 & 3.2 & 3.0 \\
\hline Semi-processed products & 18.3 & 15.3 & 7.0 & 7.7 \\
\hline Fully processed products & 18.1 & 15.4 & 11.9 & 13.6 \\
\hline
\end{tabular}

Notes: 1. As a percentage of total tariff lines

2. Domestic tariff peaks are defined as those exceeding three times the overall simple average $M F N$ rate.

3. International tariff peaks are defines as those exceeding $15 \%$.

Source: WTO (1998), Tables III.1 and III.4; and WTO (2002), Tables III.1 and III.2. 
Table 3: Nominal Tariff Rates and Dispersion in Selected East Asian Countries, $2000(\%)$.

\begin{tabular}{|c|c|c|c|c|}
\hline & Tariff measure & All products & Primary products & Manufacturing \\
\hline \multirow[t]{3}{*}{ China } & Mean & 17.48 & 14.27 & 17.35 \\
\hline & CV & 71.28 & 102.31 & 58.76 \\
\hline & Weighted mean & 20.5 & 19.32 & 16.12 \\
\hline \multirow[t]{3}{*}{ Indonesia } & Mean & 8.43 & 7.43 & 16.52 \\
\hline & $\mathrm{CV}$ & 127.76 & 158.55 & 119.31 \\
\hline & Weighted mean & 11.23 & 5.23 & 25.58 \\
\hline \multirow[t]{3}{*}{ Malaysia } & Mean & 10.2 & 5.2 & 14.7 \\
\hline & $\mathrm{CV}$ & 200.49 & 181.35 & 172.24 \\
\hline & Weighted mean & 13.5 & 11.87 & 16.3 \\
\hline \multirow[t]{3}{*}{ Philippines } & Mean & 7.6 & 6.15 & 8.36 \\
\hline & $\mathrm{CV}$ & 93.82 & 56.91 & 18.90 \\
\hline & Weighted mean & 7.51 & 4.83 & 8.58 \\
\hline \multirow[t]{3}{*}{ Thailand } & Mean & 18.48 & 16.34 & 19.32 \\
\hline & $\mathrm{CV}$ & 84.42 & 48.10 & 55.40 \\
\hline & Weighted mean & 16.82 & 13.75 & 17.89 \\
\hline \multirow[t]{3}{*}{ Vietnam } & Mean & 16.52 & 19.3 & 14.6 \\
\hline & $\mathrm{CV}$ & 113.44 & 124.5 & 102.3 \\
\hline & Weighted mean & 15.2 & 17.2 & 13.4 \\
\hline
\end{tabular}

Notes: $\quad$ CV: Coefficient of variation (standard deviation as a percentage of the mean)

Source: Compiled from individual country tariff schedules available from the Asia Pacific Economic Cooperation (APEC) Secretariat's online data base, www.apectariff.org. 
Figure 1: Malaysia: Growth (1965-2000) and Unemployment (1979-2000), (\%)

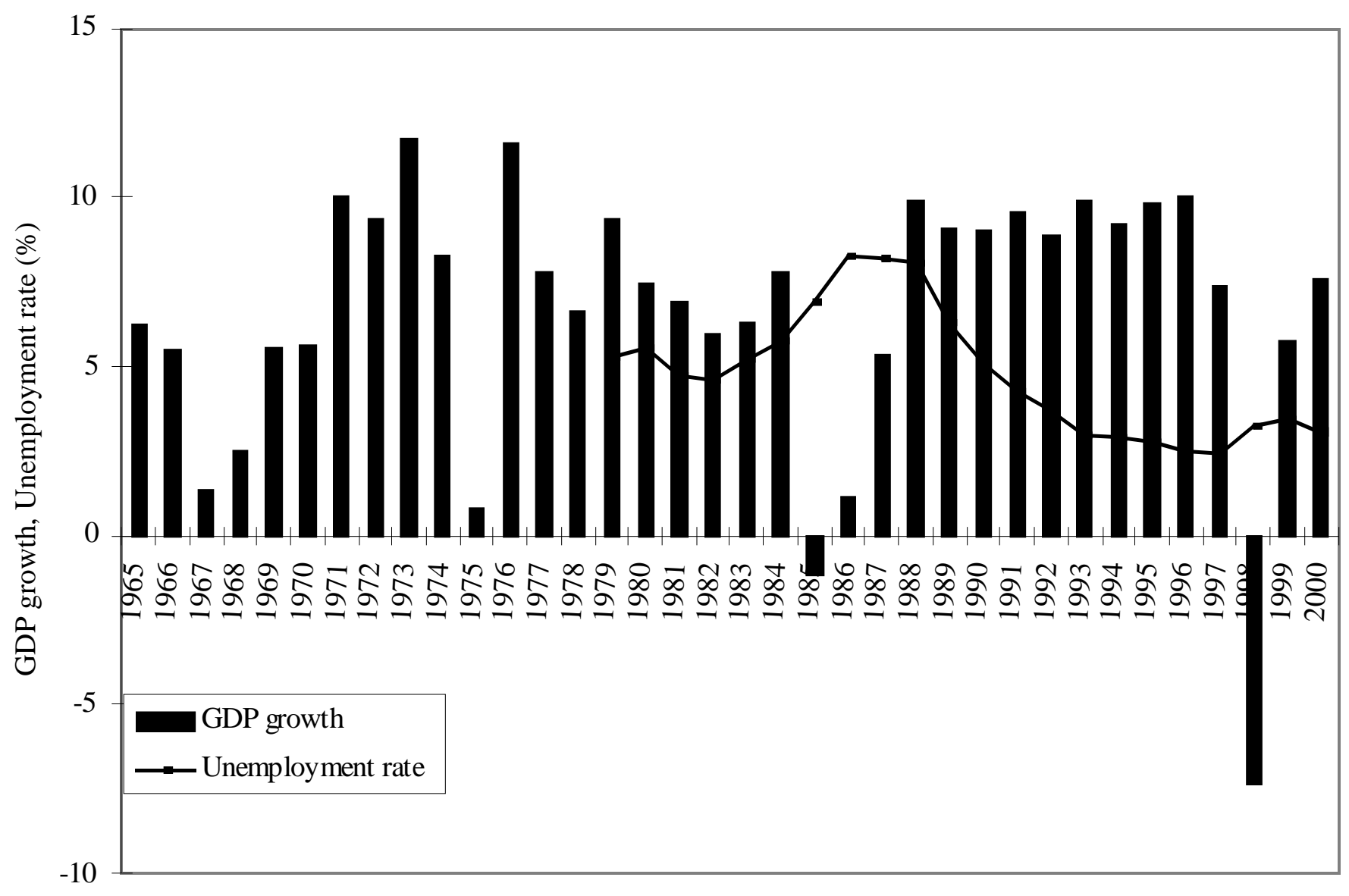

Source: Ministry of Finance, Economic Survey, Kuala Lumpur (various issues). 